\title{
ANALISIS KEMAMPUAN MENYELESAIKAN SOAL HOTS FISIKA SISWA SMA DI KOTA MAJENE
}

\author{
Sutrisno \\ Universitas Sulawesi Barat \\ e-mail: sutrisno@unsulbar.ac.id
}

\begin{abstract}
Abstrak
Penelitian ini bertujuan untuk mengukur kemampuan siswa dalam menyelesaikan soal HOTS pada mata pelajaran fisika tingkat SMA di Kota Majene. Subjek penelitian ini adalah sekolah tingkat menengah atas yang ada di kota Majene, Sulawesi Barat. Jenis penelitian yang digunakan dalam penelitian ini adalah penelitian kuantitatif dengan pendekatan deskriptif. Penelitian ini menggunakan pendekatan deskriptif dengan tujuan untuk mendeskripsikan objek penelitian ataupun hasil penelitian. analisis data pada penelitian ini dengan menjadikan KKM sebagai standar ketuntasan peserta didik. Tes berupa soal essay yang memenuhi kriteria hots, yaitu menganalisis (C4), Mengevaluasi (C5), dan Mengkreasi (C6). Analisis data akan menggunakan berbagai teknik analisis yang sesuai jenis data dan metode pengumpulan data yang digunakan. Pengolahan data bertujuan untuk mendapatkan kesimpulan berdasarkan tujuan dari penelitian. Hal ini sesuai dengan hasil penelitian berupa persentase peserta didik yang sudah memiliki HOTS rendah dalam menyelesaikan soal menganalisis (C4) sebesar 27,09\%, soal mengevaluasi (C5) sebesar 24,79\%, dan sebesar 3,94\% untuk soal mencipta (C6).
\end{abstract}

Kata Kunci: HOTS, Fisika, Pendekatan Deskriptif

\section{ANALYSIS OF ABILITY TO SOLVE HOTS QUESTIONS OF HIGH SCHOOL PHYSICS STUDENTS IN THE CITY OF MAJENE}

\begin{abstract}
This study aims to measure students' ability to solve HOTS questions in high school physics subjects in Majene City. The subject of this research is a senior high school in the city of Majene, West Sulawesi. The type of research used in this research is quantitative research with a descriptive approach. This study uses a descriptive approach with the aim of describing the object of research or research results. analysis of the data in this study by making the KKM as a standard for students' mastery. The test is in the form of essay questions that meet the hots criteria, namely identifying (C4), evaluating (C5), and creating (C6). Data analysis will use various analytical techniques according to the type of data and data collection methods used. Data processing aims to obtain conclusions based on the objectives of the study. This is in accordance with the results of the study in the form of the percentage of students who already have low HOTS in solving analyzing problems (C4) of 27.09\%, evaluating questions (C5) of $24.79 \%$, and $3.94 \%$ for creating questions (C6).
\end{abstract}

Keywords: HOTS, Physics, Descriptive Approach

\section{PENDAHULUAN}

Pendidikan merupakan pondasi awal dari pengembangan sumber daya dalam sebuah negara [1]. Hal ini menjadi dasar bagi suatu negara untuk meningkatkan kualitas pendidikan di Indonesia. Melalui pendidikan yang berkualitas, sumber daya siswa akan berkembang. Untuk mewujudkan generasi yang berkualitas. Sejalan dengan Undang-Undang Republik Indonesia Nomor 20 Tahun 2003, tentang sistem pendidikan, Bab II pasal 3 menyatakan bahwa Pendidikan Nasional 
berfungsi mengembangkan kemampuan dan membentuk watak serta peradaban bangsa yang bermartabat dalam rangka mencerdaskan kehidupan bangsa, bertujuan mengembangkan potensi siswa agar menjadi manusia yang beriman dan bertaqwa kepada Tuhan Yang Maha Esa, berakhlak mulia, sehat, berilmu, cakap, kreatif, mandiri dan menjadi warga Negara yang demokratis serta bertanggung jawab [2].

Fisika merupakan salah satu ilmu dasar yang mencakup tentang fakta, konsep, prinsip, hukum, postulat, teori dan metodologi penelitian [3]. Oleh karena itu, dibutuhkan pemecahan masalah dalam soal fisika dengan berpikir kritis untuk mencapai cakupan tersebut. Dalam hal ini yang ramai di era globalisasi adalah High Order Thinking Skills (HOTS). HOTS atau keterampilan berpikir tingkat tinggi merupakan bagian dari taksonomi Bloom hasil revisi yang berupa kata kerja operasional yang terdiri dari analyze (C4), evaluate (C5) dan create (C6) yang dapat digunakan dalam penyusunan soal [4].

HOTS adalah proses pemikiran yang melibatkan aktivitas mental dalam upaya mengeksplorasi pengalaman yang kompleks, reflektif dan kreatif yang dilakukan secara sadar untuk mencapai tujuan pembelajaran dan menghasilkan banyak solusi produktif [5]. HOTS terdiri dari dua komponen yaitu keterampilan berpikir kritis dan kreatif [6]. Penerapan HOTS dalam pemecahan soal fisika diharapkan mampu meningkatkan kemampuan siswa. Dengan berpikir kritis, mampu meningkatkan kemampuan pemahaman konsep siswa. Oleh karena itu, penerapan HOTS dalam soal fisika diharapkan secara merata diterapkan oleh pendidik-pendidik yang ada di sekolah [7].

Majene merupakan salah satu kota di Sulawesi Barat. Tercatat Sulawesi Barat masih menempati posisi tiga terbawah rerata hasil ujian nasional mata pelajaran Fisika tahun pelajaran 2018/2019. Untuk tahun pelajaran
2019/2020 ujian nasional ditiadakan karena pandemi covid 19. Rendahnya hasil ujian nasional pada mata pelajaran fisika untuk wilayah Sulawesi Barat tahun pelajaran 2018/2019 menunjukkan bahwa kemampuan siswa dalam memecahkan soal fisika masih rendah. Hal ini diperkirakan penyebabnya adalah tidak mampunya siswa dalam menyelesaikan soal HOTS untuk mata pelajaran fisika.Tujuan dalam penelitian ini adalah untuk mengukur kemampuan siswa dalam menyelesaikan soal HOTS pada mata pelajaran fisika tingkat SMA di Kota Majene.

\section{METODE}

Model penelitian yang digunakan adalah metode penelitian kuantitatif dengan menggunakan pendekatan deskriptif. Metode penelitian kuantitatif adalah metode penelitian yang berlandaskan pada filsafat positivisme, digunakan untuk meneliti pada populasi atau sampel tertentu, teknik pengambilan sampel pada umumnya dilakukan secara random, pengumpulan data menggunakan instrumen penelitian, analisis data bersifat kuantitatif/statistik dengan tujuan untuk menguji hipotesis yang telah ditetapkan [8]. Penelitian ini menggunakan pendekatan deskriptif dengan tujuan untuk mendeskripsikan objek penelitian ataupun hasil penelitian. Pengertian deskriptif menurut adalah metode yang digunakan untuk mendeskripsikan atau memberi gambaran terhadap objek yang diteliti melalui data atau sampel yang telah terkumpul sebagaimana adanya [9].

\section{Lokasi Penelitian}

Penelitian ini dilakukan di Kota Majene, Kabupaten Majene, Provinsi Sulawesi Barat.

\section{Subjek Penelitian}

Subjek penelitian ini adalah sekolah tingkat menengah atas yang ada di kota Majene, Sulawesi Barat. 


\section{Tahapan Penelitian}

Penelitian ini terdiri dari tiga tahap penelitian, yaitu tahap persiapan, tahap pelaksanaan, dan tahap akhir.

\section{Analisis Data}

Analisis data pada penelitian ini dengan menjadikan KKM sebagai standar ketuntasan peserta didik. Tes berupa soal essay yang memenuhi kriteria hots, yaitu menganalisis (C4), Mengevaluasi (C5), dan Mengkreasi (C6). Analisis data akan menggunakan berbagai teknik analisis yang sesuai jenis data dan metode pengumpulan data yang digunakan.

\section{HASIL DAN DISKUSI}

Penelitian ini dilakukan di 3 SMA yang ada di Kota Majene, yaitu: SMA Negeri 1 Majene, SMA Negeri 2 Majene, dan SMA Negeri 3 Majene. Kelas yang diteliti adalah kelas XI IPA. Adapun jumlah siswa di masingmasing sekolah adalah sebagai berikut:
Tabel 1. Jumlah Siswa Kelas XI IPA di Masingmasing Sekolah

\begin{tabular}{ccc}
\hline No. & Sekolah & Jumlah Siswa \\
\hline 1 & $\begin{array}{c}\text { SMA Negeri 1 } \\
\text { Majene }\end{array}$ & 33 \\
\cline { 2 - 2 } 2 & $\begin{array}{c}\text { SMA Negeri 2 } \\
\text { Majene }\end{array}$ & 31 \\
\hline 3 & $\begin{array}{c}\text { SMA Negeri 3 } \\
\text { Majene }\end{array}$ & 26 \\
\cline { 2 - 2 } &
\end{tabular}

Pengambilan data dilakukan dengan pembagian soal HOTS fisika sebanyak 9 nomor dengan masing 3 jenis soal pada tingkatan HOTS. Dari data ketiga sekolah tersebut, maka persentase masing-masing tingkatan soal dapat dilihat pada tabel 2, yang merupakan hasil ratarata dari ketiga soal untuk masing-masing tingkatan soal. Data ini akan menunjukkan seberapa besar tingkat persentase kemampuan siswa SMA di Kota Majene dalam menyelesaikan soal HOTS fisika. Untuk grafik persentase kemampuan siswa dalam menyelesaikan soal HOTS fisika SMA kelas XI IPA di kota majene dapat dilihat pada gambar 1.

Tabel 2. Persentase Siswa dalam Menyelesaikan Soal HOTS Fisika pada Masing-Masing Tingkatan

\begin{tabular}{cccccc}
\hline \multirow{2}{*}{ No. } & \multirow{2}{*}{ Sekolah } & \multicolumn{3}{c}{ Persentase Tingkatan Soal } & \multirow{2}{*}{ Rata-Rata } \\
\cline { 3 - 5 } & & $\mathbf{C 4}$ & $\mathbf{C 5}$ & $\mathbf{C 6}$ & \\
\hline 1 & SMAN 1 Majene & $28,28 \%$ & $33,33 \%$ & $0,00 \%$ & $20,58 \%$ \\
\hline 2 & SMAN 2 Majene & $31,18 \%$ & $33,33 \%$ & $11,83 \%$ & $25,45 \%$ \\
\hline 3 & SMAN 3 Majene & $21,79 \%$ & $7,69 \%$ & $0,00 \%$ & $9,83 \%$ \\
\hline & Rata-Rata & $27,09 \%$ & $24,79 \%$ & $3,94 \%$ & $\mathbf{1 8 , 6 1 \%}$ \\
\hline & Kategori & Rendah & Rendah & Sangat Rendah & Sangat Rendah \\
\hline
\end{tabular}

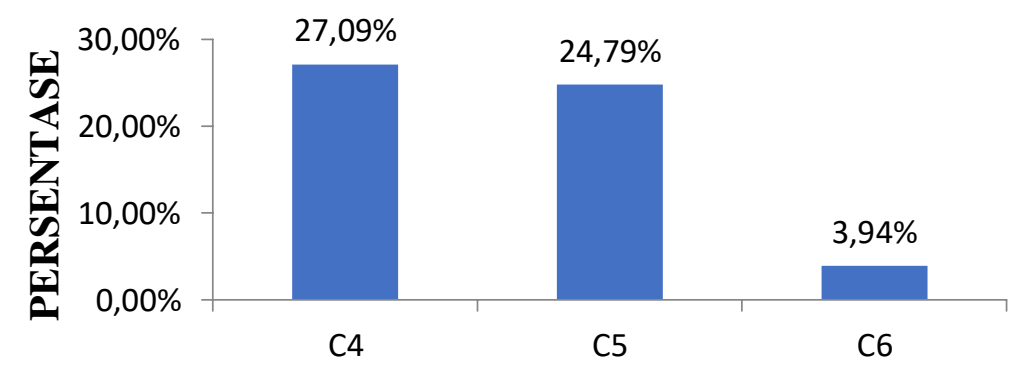

TINGKATAN SOAL

\section{Gambar 1. Persentase Kemampuan Menyelesaikan Soal HOTS Fisika Siswa SMA di Kota Majene}

Berdasarkan data yang diperoleh, untuk tingkatan soal $\mathrm{C} 4$, sekolah yang memperoleh persentase paling tinggi adalah SMA Negeri 2 Majene dengan persentase $31,18 \%$. Namun 
persentase tersebut masuk dalam kategori rendah, yang menandakan bahwa kemampuan siswa SMA kelas XI IPA di Kota Majene dalam menyelesaikan soal tingkatan $\mathrm{C} 4$ masih tergolong rendah. Untuk tingkatan soal C5 pun masuk dalam kategori rendah. Hal ini dapat dilihat pada persentase tertinggi diraih oleh SMA Negeri 1 Majene dan SMA Negeri 2 Majene yang memperoleh 33,33\%. Persentase tersebut masuk dalam kategori rendah. untuk tingkatan soal C6, terlihat pada masing-masing tabel hasil di tiap sekolah, banyak yang menjawab salah sehingga mendapatkan pon nol. SMA Negeri 1 Majene dan SMA Negeri 3 Majene, masing-masing memperoleh persentase $0,00 \%$ dan hanya SMA Negeri 2 Majene yang memperoleh persentase $11,83 \%$. Hasil yang didapatkan ini berada pada kategori sangat rendah.

Rata-rata persentase pada tingkatan soal $\mathrm{C} 4$ adalah $27,09 \%$, hasil ini berada pada kategori rendah, sehingga dapat dikatakan bahwa kemampuan siswa SMA di Kota Majene dalam menyelesaikan soal HOTS tingkatan C4 masih rendah. Rata-rata persentase pada tingkatan C5 adalah 24,79\%. Hasil yang juga menempatkan pada kategori rendah, sehingga dapat dikatakan bahwa kemampuan siswa SMA di Kota Majene dalam menyelesaikan soal HOTS tingkatan C5 masing rendah. rata-rata persentase pada tingkatan soal C6 adalah 3,94\%, masuk dalam kategori sangat rendah, sehingga dapat dikatakan bahwa kemampuan siswa SMA di Kota Majene dalam menyelesaikan soal HOTS tingkatan C6 masing sangat rendah. Setelah data yang diperoleh dari ketiga SMA yang ada di Kota Majene dirataratakan, memperoleh persentase sebesar $18,61 \%$. Hasil ini dapat dikatakan bahwa kemampuan siswa SMA di kota Majene dalam menyelesaikan soal HOTS fisika masih sangat rendah.

\section{SIMPULAN DAN SARAN Simpulan}

Berdasarkan data yang diuraikan, maka dapat disimpulkan bahwa kemampuan siswa SMA Negeri 1 Majene dalam menyelesaikan soal HOTS fisika masih rendah, siswa SMA Negeri 2 Majene masih rendah, dan siswa SMA Negeri 3 Majene masih sangat rendah. Secara keseluruhan kemampuan siswa dalam menyelesaikan soal HOTS fisika di Kota
Majene masih sangat rendah. Hal ini berdasar pada data yang diperoleh sebesar $18,61 \%$.

\section{Saran}

Hasil penelitian yang diperoleh mengarah pada pentingnya guru dalam meningkatkan pembelajaran agar siswa mampu dalam menyelesaikan soal HOTS, khususnya pada mata pelajaran fisika. Diharapkan guru fisika membiasakan siswa mengerjakan soalsoal HOTS agar dengan kebiasaan mengerjakan soal HOTS, siswa mudah menaklukkan soal tingkat $\mathrm{C} 4, \mathrm{C} 5$, dan $\mathrm{C} 6$, serta dapat berpikir kritis.

Saran untuk peneliti selanjutnya, data ini merupakan data yang diperoleh dari 3 SMA yang ada di Kota Majene. Belum melibatkan sekolah-sekolah yang lain, contohnya Madrasah Aliyah. Jika ingin melanjutkan penelitian ini, diharapkan dapat menjangkau lebih luas lagi sekolah-sekolah yang ada di Kabupaten Majene, maupun di provinsi.

\section{DAFTAR PUSTAKA}

[1] Pratama, N. S., \& Istiyono, E. (2015). Studi Pelaksanaan Pembelajaran Fisika berbasis Higher Order Thinking (HOTS) pada Kelas $X$ di SMA Negeri Kota Yogyakarta. Prosiding Seminar Nasional Fisika Dan Pendidikan Fisika (SNFPF), 6(1), 104-112.

[2] Depdiknas. (2003). Undang-Undang RI Nomor 20 , Tahun 2003, tentang Sistem Pendidikan Nasional.

[3] Pratama, N. S., \& Istiyono, E. (2015). Studi Pelaksanaan Pembelajaran Fisika berbasis Higher Order Thinking (HOTS) pada Kelas $X$ di SMA Negeri Kota Yogyakarta. Prosiding Seminar Nasional Fisika Dan Pendidikan Fisika (SNFPF), 6(1), 104-112.

[4] Fanani, M. Z. (2018). Strategi Pengembangan Soal Hots Pada Kurikulum 2013. Edudeena, 2(1), 57-76. https://doi.org/10.30762/ed.v2i1.582

[5] Dinni, H. N. (2018). HOTS ( High Order Thinking Skills ) dan Kaitannya dengan Kemampuan Literasi Matematika. Prisma, $1,170-176$ 
[6] Ahmad, S., Prahmana, R. C. I., Kenedi, A. K., Helsa, Y., Arianil, Y., \& Zainil, M. (2018b). The instruments of higher order thinking skills. Journal of Physics: Conference Series, 943(1). https://doi.org/10.1088/1742$\underline{6596 / 943 / 1 / 012053}$

[7] Malik, A., Ertikanto, C., \& Suyatna, A. (2015). Deskripsi Kebutuhan HOTS Assessment Pada Pembelajaran Fisika dengan Metode Inkuiri Terbimbing. Prosiding Seminar Nasional Fisika (EJournal) SNF2015, IV, 1-4.

[8] Sugiyono. 2019. Metode penelitian Kuantitatif Kualitatif dan $R \& D$. Bandung. Alfabeta.

[9] Sugiyono. 2012. Metode penelitian Kuantitatif Kualitatif dan $R \& D$. Bandung. Alfabeta. 